\title{
PESAN PROMOSI DALAM WEBSITE BADAN AMIL ZAKAT NASIONAL (BAZNAS)
}

\author{
Bagus Wira Prasetia \\ Alumnus Pasca Sarjana UIN Sunan Ampel, Surabaya \\ bagus.wira.pras@gmail.com
}

\begin{abstract}
Abstrak: BAZNAS merupakan badan resmi pemerintah yang memiliki tugas dan fungsi dalam menyalurkan zakat, infak, dan sedekah (ZIS). BAZNAS telah berhasil menghimpun dana ZIS dengan jumlah besar termasuk melalui jalur digital. Keberhasilan ini tidak terlepas dari promosi produk program BAZNAS lewat mediamedianya, salah satunya adalah media website. Kajian ini membahas pesan promosi yang ada dalam website baznas.go.id sebagai bagian salah satu media promosi dalam mencapai keberhasilan BAZNAS. Teori yang digunakan adalah teori perancangan pesan. Kajian ini menggunakan pendekatan kualitatif deskriptif dengan memaparkan hasil kajian melalui uraian dan gambar. Sumber data website diakses antara September 2019 hingga Januari 2020. Hasil temuan dari kajian ini adalah message content rational appeal ditunjukkan dengan manfaat program serta akuntabilitas lembaga. Emotional appeal mengutamakan emosi positif dengan moral appeal lewat pemberdayaan masyarakat. Message structure berupa one-side argument dengan alur presentasi klimaks serta conclusion drawing yang telah dikunci pemahamannya. Variasi message format pesan promosi baznas.go.id yang berupa teks, gambar, dan video, ditunjang dengan infografik serta kualitas gambar dan video yang bagus, dan warna hijau sebagai warna dominan promosi BAZNAS. Message source pada pesan promosinya mengutamakan expertise dan trustworthiness. Terutama pada pesan promosi berupa pesan penghargaan yang menggunakan kredibilitas pesan expertise dan trustworthiness hingga pada tingkat dunia.
\end{abstract}

Kata kunci: pesan, promosi, website, BAZNAS

Promotional Message in the Website of Badan Amil Zakat Nasional (BAZNAS). Abstract: BAZNAS is an official government institution having tasks and functions of contributing zakah, infaq, and alms. BAZNAS has succeeded to gather large amount of donations, including through digital technology. The success is inseparable from the promotion of BAZNAS programs through its media, one of whose is a website. This study reveals promotional messages in the website of baznas.go.id as a part of promotional media in the success of BAZNAS. It applies a theory of designing a message. It uses descriptive qualitative approach by describing the result through descriptions and pictures. Website data source was accessed from September 2019 to January 2020. It results in the message content that rational appeal is shown with its program's benefits and institutional accountability. Its emotional appeal emphasizes positive emotion combined with moral appeal through community development. Its message structure presents a one-side argument with climax presentation plot and closed conclusion drawing. Its variations of promotional content from baznas.go.id, are supported with info-graphic and good quality of pictures and videos. Green is dominant color for promoting BAZNAS. Message source to its promotional content emphasizes expertise and trustworthiness, especially acknowledgement message uses message credibility of expertise and trustworthiness of world level.

Key words: message, promotion, website, BAZNAS 


\section{Pendahuluan}

Badan Amil Zakat Nasional (BAZNAS) merupakan badan resmi dan satu-satunya yang dibentuk oleh pemerintah berdasarkan Keputusan Presiden RI No. 8 Tahun 2001 yang memiliki tugas dan fungsi menghimpun dan menyalurkan zakat, infak, dan sedekah (ZIS) pada tingkat nasional. Lahirnya Undang-Undang Nomor 23 Tahun 2011 tentang Pengelolaan Zakat makin mengukuhkan peran BAZNAS sebagai lembaga yang berwenang melakukan pengelolaan zakat secara nasional. Dalam UU tersebut, BAZNAS dinyatakan sebagai lembaga pemerintah nonstruktural yang bersifat mandiri dan bertanggung jawab kepada Presiden melalui Menteri Agama ${ }^{1}$ BAZNAS sebagai lembaga penghimpun ZIS yang dibentuk oleh pemerintah, tentu pengelolaannya sangat profesional dan bisa menjadi salah satu contoh pengelolaan ZIS oleh lembaga-lembaga selainnya. Pada tahun 2018, BAZNAS dapat menghimpun dana sekitar 8,1 triliun. Pada tahun 2019 menargetkan untuk bisa menghimpun hingga 10 triliun. ${ }^{2}$ Angka ini tentu merupakan angka yang cukup besar. Butuh sebuah kepercayaan, strategi promosi, dan penjualan yang sangat bagus untuk bisa menghimpun dana yang begitu besar.

\footnotetext{
1 "Tentang BAZNAS," baznas.go.id, diakses 15 September 2019. https://baznas.go.id/profil

2 "Baznas Targetkan Himpun Zakat Rp 3,5 Triliun di Ramadan," Liputan6.com, diakses 5 september 2019. https://www.liputan6.com/ramadan/read/3970782/b aznas-targetkan-himpun-zakat-rp-35-triliun-diramadan

3 Yulistyne Kasumaningrum, "Dana Zakat yang Dihimpun Lewat Teknologi Digital Setiap Tahun Meningkat," PikiranRakyat.com, diakses 10 oktober 2019. https://www.pikiran-rakyat.com/ekonomi/pr01320418/dana-zakat-yang-dihimpun-lewatteknologi-digital-setiap-tahun-meningkat

${ }^{4}$ Nur Khansa Ranawati, "BAZNAS Targetkan 15\% Penerimaan Zakat dari Layanan Digital,"
}

Pada tahun 2018, penerimaan BAZNAS melalui pembayaran digital termasuk website, berada pada kisaran $8 \%$ dari total penghimpunan ZIS. ${ }^{3}$ Tentu angka ini sangatlah besar. Jika dihitung $8 \%$ dari 8,1 triliun adalah sebesar 658 miliar. Pada tahun 2019 ini, per Oktober diperkirakan nilainya mencapai $13,7 \%$. Kemudian pada tahun 2020, BAZNAS menargetkan untuk meningkat menjadi $15 \% .{ }^{4}$

Di era industri 4.0, memasarkan dan mempromosikan produk melalui kanal digital sudah tidak asing lagi. Bahkan pemasaran di dunia digital dan internet, adalah salah satu kanal yang bisa mendorong meningkatnya penjualan suatu produk. ${ }^{5}$ Peningkatan penjualan produk program di dunia digital, tentu tidak terlepas dengan bentuk komunikasi yang disampaikan kepada komunikan. Bentuk komunikasi yang baik akan menunjang komunikan untuk mengambil keputusan pembelian produk program yang dipromosikan. ${ }^{6}$ Sehingga dari sini dapat ditarik bahwa keberhasilan penerimaan ZIS oleh BAZNAS melalui baznas.go.id, tidak terlepas dari bentuk pesan promosi yang ada di dalam website. Maka dari itu sangat menarik untuk mengkaji, bagaimana pesan promosi BAZNAS yang disampaikan melalui website

AyoBandung.com, diakses 10 November 2019 https://www.ayobandung.com/read/2019/11/06/693 47/baznas-targetkan-15-penerimaan-zakat-darilayanan-digital

${ }^{5}$ Theresia Pradiani, "Pengaruh Sistem Pemasaran Digital Marketing terhadap Peningkatan Volume Penjualan Hasil Industri Rumahan," Jurnal JIBEKA, Vol. 11 No. 2 (2017), 46-53.

6 Sinta Petri Lestarsi, "Hubungan Komunikasi Pemasaran dan Promosi dengan Keputusan Memilih Jasa Layanan Kesehatan (Studi pada Rumah Sakit Islam Lumajang)," Interaksi: Jurnal IImu Komunikasi, Vol. 4 No. 2 (2015): 146 
baznas.go.id dalam mempromosikan produk program untuk menghimpun dana ZIS dari masyarakat.

Website merupakan media informasi yang bisa diakses oleh banyak orang. Menurut Bekti, website adalah kumpulan halamanhalaman yang digunakan untuk menampilkan informasi teks, gambar diam atau gerak, animasi, suara, dan atau gabungan dari semuanya, baik yang bersifat statis maupun dinamis yang membentuk satu rangkaian bangunan yang saling terkait, yang masing-masing dihubungkan dengan jaringan-jaringan halaman. ${ }^{7}$ Melalui media website ini, banyak informasi yang bisa disampaikan tanpa harus menghabiskan banyak lembaran-lembaran kertas seperti halnya media cetak. Termasuk di dalamnya juga dapat memuat promosi bahkan dapat juga digunakan untuk melakukan pembayaran zakat. ${ }^{8}$

Kajian mengenai website ini tentu juga tidak lepas dari kepentingan dalam usaha amar makruf nahi mungkar, yaitu berdakwah untuk menyiarkan kebaikan ke seluruh penjuru negeri. BAZNAS melalui media website, mendakwahkan syiar Islam lewat pendekatan pembangunan masyarakat yang berbasiskan pengoptimalan pengumpulan zakat, infak, dan sedekah. Adanya bentuk dakwah ini, tentu akan makin mendengungkan bahwa dana ZIS benarbenar dapat membantu dan membangun masyarakat. Sekaligus memberikan contoh berupa dakwah bilhal dalam bentuk perilaku

\footnotetext{
${ }^{7}$ Humairah Bintu Bekti, Mahir Membuat Website dengan AdobeDreamweaver CS6, CSS dan JQuery. (Yogyakarta: Andi, 2015), 35.

8 Ditya Pandu Akhmadi, "Cara Bayar Zakat Online Melalui Situs Web Baznas," Tirto.id, diakses 10 Oktober 2019. https://www.tirto.id/cara-bayar-zakatonline-melalui-situs-web-baznas-dtLd
}

atau action membantu mereka yang membutuhkan dalam dakwah Islam yang rahmatan li al-alamin. Hal ini dibuktikan di tahun 2019 ada sekitar 755.536 mustahik yang telah dibantu, dan melahirkan 349 Warung Z-Mart, 6 unit Lembaga Keuangan Baznas Microfinance Desa, 4 lumbung pangan, 18 balai ternak, dan 103 titik Zakat Community Development. 9 Besarnya manfaat pengelolaan ZIS sebagai bagian dari dakwah bilhal, yang tak lepas dari besarnya penerimaan ZIS, menarik untuk dikaji agar pengoptimalan pengelolaan ZIS dapat menjadi contoh bagi lembaga lain dalam mengelola ZIS. Termasuk salah satunya dengan memanfaatkan website sebagai media promosi dengan rencana pesan yang dapat menarik para muzaki untuk menyalurkan ZIS-nya. Untuk itu kajian ini hendak menjawab rumusan, bagaimana bentuk pesan promosi dalam website baznas.go.id? Range waktu dalam pengamatan sumber data adalah September 2019 hingga Januari 2020. Data diperoleh dengan cara pengamatan serta mendokumentasikan lewat save page htm full agar data teks dan gambar bisa tersimpan. Kajian untuk menganalisis pesan promosi menggunakan teori perancangan pesan.

Kajian ini menggunakan pendekatan deskriptif kualitatif. Kajian kualitatif deskriptif adalah kajian yang menggambarkan data dengan kata-kata atau kalimat yang dipisahkan menurut kategori untuk memperoleh simpulan. ${ }^{10}$ Tahapan

\footnotetext{
9 "Pengumpulan Zakat 2019 Lampaui Target," Media Indonesia, diakses 30 Desember 2019. https://mediaindonesia.com/read/detail/280014pengumpulan-zakat-2019-lampaui-target 10 Suharsimi Arikunto, Prosedur Penelitian Suatu Pendekatan Praktik, edisi revisi 6, (Jakarta: Rineka Cipta, 2009), 195.
} 
kajian dimulai dengan melakukan pengamatan konten-konten yang ada di baznas.go.id. Kemudian mereduksi kontenkonten yang berkaitan dengan pesan promosi. Data disajikan dalam bentuk teks uraian dan gambar. Mengingat keterbatasan dalam penulisan, penyajian data akan disajikan hanya sampel sebagai data yang mereprensentasikan. Sampel data yang disajikan memiliki kriteria sebagai data yang mewakili representasi dari variabel kajian yang berkaitan dengan pesan promosi. Baik itu dari segi konten pesan, struktur pesan, format pesan, serta sumber pesan yang merujuk pada ketercapaian tujuan promosi produk program. Sehingga data yang tidak berhubungan dengan promosi produk maupun program BAZNAS, tidak disajikan dalam kajian ini.

Beberapa kajian yang menelaah website sebagai media promosi di antaranya meneliti dari sudut pandang pembuatan website yang mampu menjadi media promosi yang tepercaya. ${ }^{11}$ Selain itu ada juga kajian promosi yang mengambil sudut pandang dari efektivitasnya, seperti kajian Wavin dalam menelaah efektivitas website Dinas Pariwisata dan Kebudayaan bagi Wisatawan. ${ }^{12}$ Kajian mengenai komunikasi pemasaran yang berhubungan dengan zakat di antaranya yaitu kajian Milla Rahma Fiqhyany dan Ari Prasetyo yang menelaah tentang pengaruh komunikasi pemasaran

\footnotetext{
${ }^{11}$ Andi Dwi Riyanto, "Pembuatan Website Sebagai Media Promosi yang Terpecaya," Seminar Nasional Informatika (SEMNASIF), Vol. 1 No.1 (2015): 34.

${ }^{12}$ Walvin Naibaho dan Firdaus Yusrizal, "Efektivitas Website Dinas Pariwisata Dan Kebudayaan Provinsi Jawa Barat Sebagai Media Informasi Bagi Wisatawan," Jurnal Online Mahasiswa FISIP, Vol. 4 No. 2 (2017): 11. ${ }^{13}$ Milla Rahma Fiqhyany dan Ari Prasetyo, "Pengaruh Komunikasi Pemasaran Terpadu Terhadap Niat Muzakki Membayar Dana Zakat, Infaq, Shadaqah Pada Yayasan Nurul Hayat Cabang Tuban," Jurnal Ekonomi
}

pada Yayasan Nurul Hayat ${ }^{13}$ serta kajian Tarsani dalam membahas strategi komunikasi pemasaran Dompet Dhuafa dalam meningkatkan kepercayaan muzaki. ${ }^{14}$ Pada kajian lain, terdapat pula bahasan tentang tantangan serta hambatan dalam menghimpun dana ZIS melalui dunia digital seperti dalam kajian yang dilakukan oleh Ade Nur Rohim. ${ }^{15}$ Pada kajian ini memberikan sudut pandang baru dalam penghimpunan zakat, utamanya berkaitan dengan pesan promosi melalui media website. Harapannya dengan sudut pandang baru yang diambil kajian ini, akan lebih memperluas khazanah pengetahuan dalam hubungannya dakwah bilhal organisasi yang memiliki program penghimpunan dan penyaluran zakat, infak, dan sedekah di era digital.

\section{Pesan Promosi}

Website merupakan salah satu media yang bisa digunakan untuk melakukan kegiatan promosi. Media menurut Pujiriyanto adalah sarana untuk menyampaikan pesan atau informasi kepada publik dengan menggunakan berbagai unsur komunikasi grafis seperti teks, gambar, atau foto. ${ }^{16}$ Promosi atau komunikasi pemasaran adalah sarana di mana suatu atau lembaga perusahaan menginformasikan, membujuk, dan mengingatkan konsumen, baik secara langsung maupun tidak langsung mengenai

Syariah Teori dan Terapan, Vol. 1 No. 11 (2015): 813831.

${ }^{14}$ Tarsani, "Strategi Komunikasi Pemasaran Dompet Dhuafa Dalam Meningkatkan Kepercayaan Muzakki," Bricolage: Jurnal Magister Ilmu Komunikasi, Vol. 2 No. 1, (2017): 69.

${ }^{15}$ Ade Nur Rohim, "Optimalisasi Penghimpunan Zakat Melalui Digital Fundraising," Al-Balagh: Jurnal Dakwah dan Komunikasi, Vol. 4, No. 1, (2019), 59 - 90.

${ }_{16}$ Pujiriyanto, Desain Grafis Komputer: Teori Grafis Komputer, (Yogyakarta: Andi, 2005), 15. 
produk dan merek yang dijual. ${ }^{17}$ Promosi merupakan salah satu variabel dalam bauran pemasaran yang sangat penting dilaksanakan oleh perusahaan dalam memasarkan produk jasa. Kegiatan promosi berfungsi sebagai alat komunikasi antara perusahaan dan konsumen, serta alat untuk memengaruhi konsumen dalam kegiatan pembelian atau penggunaan jasa sesuai dengan keinginan dan kebutuhannya. ${ }^{18}$ Menurut Fandy Tjiptono, tujuan utama promosi adalah menginformasikan, memengaruhi, dan membujuk, serta mengingatkan pelanggan sasaran tentang perusahaan dan bauran pemasarannya. ${ }^{19}$

Pesan dalam sebuah proses komunikasi pemasaran adalah sekumpulan simbol yang dikirimkan oleh pengirim. Pesan terdiri dari kata-kata maupun simbol yang dibuat oleh komunikator yang harapannya dapat dimengerti oleh komunikan. ${ }^{20}$ Sebuah pesan yang efektif adalah pesan yang bisa dimengerti oleh komunikan. Salah satu indikator bahwa pesan berhasil adalah komunikan melakukan apa yang diinginkan oleh komunikator. Pesan dalam sebuah rancangan yang efektif terdiri dari beberapa variable, yaitu: isi pesan (message content), struktur pesan (message structure), format pesan (message format), sumber pesan (message source). ${ }^{21}$

Message content yakni menyangkut tiga macam daya tarik atau unique selling proposition (USP) yang ditawarkan kepada para audiens. Tiga macam tersebut yaitu

17 Philip Kotler dan Kevin Lane Keller, Manajemen Pemasaran, (Jakarta: Erlangga, 2010), 172.

18 Rambat Lupiyoadi, Manajemen Pemasaran Jasa Berbasis Kompetensi, edisi 3, (Jakarta: Salemba Empat, 2013), 178.

19 Fandy Tjiptono, Strategi Pemasaran, edisi 3, (Yogyakarta: Andi, 2008), 221. daya tarik rasional, emosional, dan moral. Daya tarik rasional (rational appeals) menekankan manfaat produk seperti kualitas, harga, value, atau kinerja. Daya tarik emosional (emotional appeals) berusaha memanfaatkan emosi positif (seperti humor, cinta, rasa bangga, rasa senang, dan sejenisnya) atau emosi negatif (seperti rasa takut, rasa bersalah, malu, tegang, sedih, waswas, dan seterusnya) untuk memotivasi pembelian. Daya tarik moral (moral appeals) berfokus pada upaya mendorong konsumen agar mendukung dan berpartisipasi dalam berbagai aktivitas sosial (sosial cause) lewat slogan-slogan tertentu. ${ }^{22}$

Message structure yaitu berkaitan dengan penarikan kesimpulan (conclusion drawing), one-sided arguments vs two-sided arguments, dan urutan presentasi pesan. Pilihan dalam penarikan kesimpulan ada dua, yaitu membiarkan audiens menyimpulkan sendiri pesan yang dibaca/ditontonnya, atau perusahaan yang menegaskan kesimpulan untuk para audiens. One side arguments merupakan bentuk presentasi pesan yang semata-mata hanya menegaskan keunggulan produk, sedangkan two-sided arguments menyebutkan keunggulan sekaligus kelemahan produk. Urutan penyampaian pesan, terdiri dari penyajian argumen terkuat terlebih dahulu, menggunakan pendekatan klimaks (menyajikan argumen utama di bagian akhir), dan penyajian argumen negatif kemudian ditutup dengan argumen positif atau keunggulan produk ${ }^{23}$

\footnotetext{
20 Philip Kotler dan Kevin Lane Keller, Manajemen Pemasaran, 123.

${ }^{21}$ Fandy Tjiptono, 510.

22 Ibid.

23 Ibid., 511.
} 
Message format menyangkut headline, copy, ilustrasi, dan warna jika di media cetak. Pada media radio bisa seperti kata-kata, kualitas suara, dan vokalisasi. Pada iklan televisi bisa berkaitan dengan kata-kata, warna, ilustrasi, kualitas suara, headlines, copy, dan body language. Pada produk kemasan bisa berbentuk warna, tekstur, ukuran, bentuk, dan aroma. ${ }^{24}$ Message source adalah sumber dari pesan. Berkaitan dengan kredibilitas sumber pesan yang dipengaruhi oleh tiga faktor. Pertama, yaitu expertise, pengetahuan khusus yang dimiliki komunikator untuk mendukung dan melandasi klaimnya. Kedua trustworthiness, berkenaan dengan persepsi audiens terhadap objektivitas dan kejujuran sumber pesan. Ketiga yaitu likability, yang menggambarkan daya tarik sumber pesan, semisal populer, cantik, ganteng, humoris, berpostur atletis, dan seterusnya. ${ }^{25}$

Empat variabel di atas menjadi landasan dalam mengkaji pesan promosi yang ada dalam website baznas.go.id. Lewat empat variabel ini, akan diketahui bagaimana pesan promosi yang terdapat dalam website baznas.go.id dalam menginformasikan, membujuk, ataupun mengingatkan tentang produk dan program BAZNAS. Terutama dalam menyasar masyarakat muslim sebagai pasar dari produk zakat, infak, dan sedekah.

\section{Pesan Promosi Dalam baznas.go.id}

Sebelum membahas pesan promosi baznas.go.id, perlu diperjelas terlebih dahulu tentang apa produk yang dipromosikan oleh BAZNAS. BAZNAS merupakan lembaga yang memiliki tugas dan fungsi menghimpun dan menyalurkan zakat, infak, dan sedekah (ZIS). Produk utama dari BAZNAS yaitu pelayanan dalam bentuk penghimpunan dana ZIS dari masyarakat dan menyalurkan dana ZIS tersebut untuk masyarakat yang membutuhkan. Pasar sasaran utama dari produk ZIS ini tentunya adalah masyarakat muslim. Di Indonesia sendiri, penduduk muslim merupakan penduduk mayoritas. Indonesia juga menempati negara dengan penduduk muslim terbanyak di dunia. Sebagai bentuk penyaluran, maka bagian produk yang juga tidak terpisahkan adalah program dari hasil penghimpunan dana ZIS. Produk ZIS yang dimiliki oleh BAZNAS di antaranya yaitu zakat fitrah dan zakat mal, infak, dan sedekah. Zakat mal terbagi menjadi beberapa variasi produk, yaitu zakat penghasilan, zakat emas, zakat perdagangan, zakat perusahaan, zakat saham, dan zakat reksadana.

\section{Message Content}

Agar masyarakat tertarik untuk membayar atau menunaikan zakat, infak, dan sedekah, maka perlu sebuah konten yang menarik. Bisa bentuknya berasal dari rational appeals, emotional appeals, maupun moral appeals sebagai bentuk atau unique selling proposition (USP) yang ditawarkan kepada para konsumen maupun calon konsumen. Pada tampilan homepage utama, konsumen akan melihat tampilan sebuah gambar yang memberikan informasi tentang manfaat berzakat. 


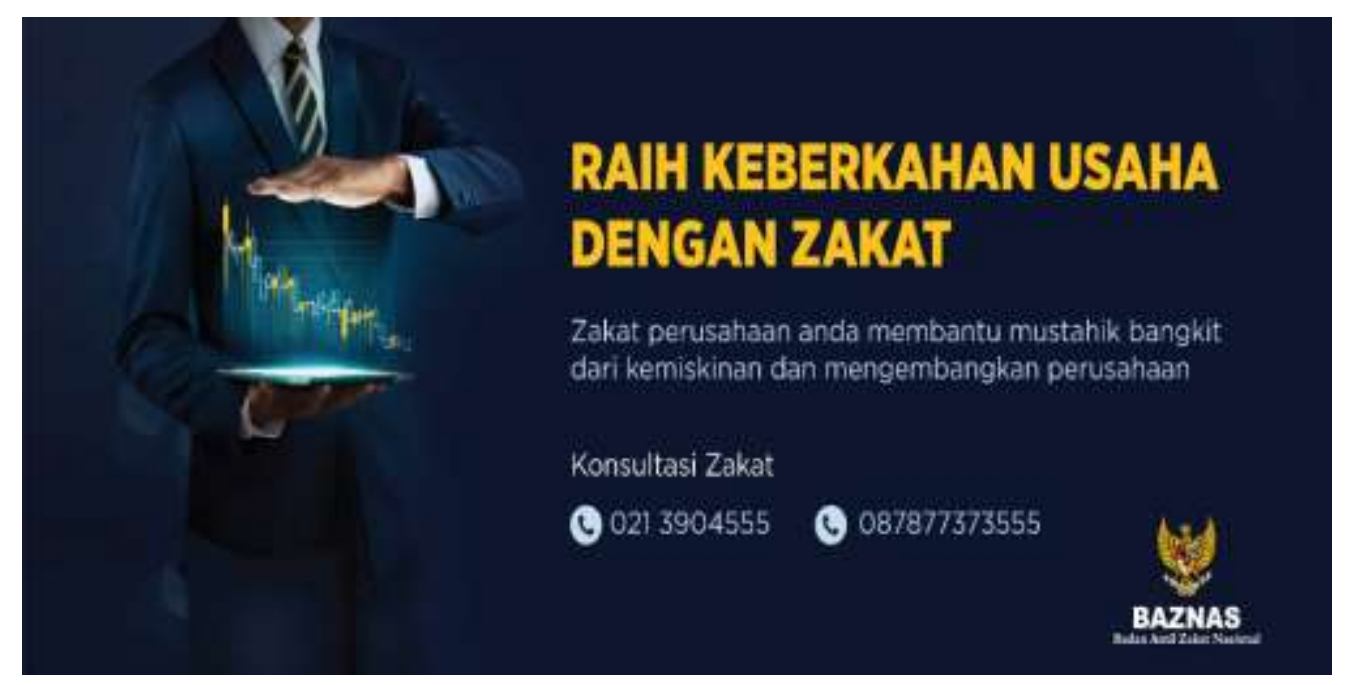

Gambar 1. Salah Satu Gambar Utama dalam Tampilan Homepage baznas.go.id

Dari konten ini dapat diketahui bahwa ada dua pendekatan konten yang ditampilkan untuk menarik konsumen membayar zakat. Kalimat yang ditampilkan adalah "raih keberkahan usaha dengan zakat." Pesan ini merupakan rational appeal dengan memberikan pemahaman bahwa dengan membayar zakat akan mendapatkan keberkahan usaha pada perusahaan. Keberkahan usaha ini akan kembali lagi kepada pembayar zakat (muzaki). Sehingga ada manfaat yang bisa diterima oleh muzaki yaitu berupa keberkahan. Meskipun keberkahan ini tidak bernilai langsung dan berwujud sesuatu yang nampak (tangible object), namun keberkahan adalah hal yang diinginkan bagi komunikan (masyarakat muslim).

Kalimat selanjutnya yaitu "Zakat perusahaan Anda membantu mustahik bangkit dari kemiskinan dan mengembangkan perusahaan." Konten pesan ini adalah moral appeal yang ditunjukkan dengan manfaat bahwa dengan membayar, berarti membantu mustahik untuk bangkit dari kemiskinan. Pendekatan ini bernilai social cause, mengajak komunikan untuk turut serta membantu mustahik untuk bangkit dari kemiskinan.

Di bawah gambar utama dalam homepage, ada cuplikan tentang pelaksanaan beberapa program BAZNAS. Pada bagian ini, selalu ada konten ter-update dengan kegiatan-kegiatan program yang dijalankan oleh BAZNAS sebagai bagian dari pemanfaatan dana zakat, infak, dan sedekah. BAZNAS memiliki beberapa program untuk masyarakat yang memang sesuai dengan kriteria penerima ZIS. Program ini merupakan hasil pengelolaan dana zakat, infak, dan sedekah. Dalam pelaksanaan programnya, BAZNAS membaginya dalam beberapa program besar. Yaitu produk kurban berdayakan desa, produk ramadan, produk program ekonomi, produk program sosial, serta produk dakwah, dan advokasi. Produk "kurban berdayakan desa" adalah program kurban untuk Hari Raya Idul Adha dengan mengambil hewan kurban dari warga binaan BAZNAS yang menjadi peternak hewan kurban. Produk ramadan adalah program yang diadakan pada bulan Ramadan yang membantu kaum muslimin dalam menyalurkan dana-dana sosial yang dimiliki 
untuk membantu masyarakat yang kurang beruntung agar dapat memenuhi kebutuhan hidupnya selama menjalankan ibadah puasa melalui berbagai program.

Ada empat produk program ekonomi BAZNAS. Pertama yaitu Zakat Community Development. Zakat Community Development (ZCD) adalah program pemberdayaan BAZNAS melalui komunitas dan desa dengan mengintegrasikan aspek dakwah, ekonomi, pendidikan, kesehatan, dan kemanusiaan secara komprehensif yang sumber pendanaannya dari zakat, infak, sedekah, dan dana sosial keagamaan lainnya. Kedua yaitu BAZNAS Microfinance. Microfinance BAZNAS adalah lembaga bantuan pembiayaan produktif kepada mustahik dengan prinsip nonprofit dalam rangka pengembangan usaha. Ketiga adalah pemberdayaan ekonomi mustahik melalui LPEM. Lembaga Pemberdayaan Ekonomi Mustahik (LPEM) merupakan salah satu lembaga yang dibentuk oleh BAZNAS berdasarkan keputusan Ketua BAZNAS Nomor 18 Tahun 2018 tanggal 29 Maret 2018 yang memiliki tugas dan fungsi untuk meningkatkan kualitas kehidupan duafa (mustahik) melalui pertanian, peternakan, perikanan, kelautan, perkebunan, dan kehutanan yang berkelanjutan berdasarkan nilai-nilai pemberdayaan zakat dan menjadi salah satu elemen dasar untuk memenuhi visi BAZNAS. Keempat adalah pemberdayaan peternak mustahik melalui LPPM. Lembaga Pemberdayaan Peternak Mustahik (LPPM) adalah lembaga program untuk menjalankan fungsi produksi ternak, pemasaran, dan pendampingan kelembagaan peternak.

Adapun untuk produk program sosial, terdapat lima macam program. Pertama yaitu Layanan Aktif Baznas. Layanan Aktif
BAZNAS (LAB) adalah program layanan darurat sosial untuk mustahik dengan model penanganan tepat sasaran, tepat waktu (cepat), dan tepat penanganan. Kedua yaitu BAZNAS Tanggap Bencana (BTB) adalah unit kerja dari Bidang Pendistribusian dan Pendayagunaan BAZNAS yang bertugas mengurangi dampak bencana yang mengakibatkan kemiskinan dan menekan risiko keterparahan kemiskinan akibat bencana. Program ketiga dari program sosial adalah Rumah Sehat BAZNAS. Yaitu suatu program yang mewakili BAZNAS dalam pelayanan kesehatan secara terpadu kepada seluruh mustahik termasuk pelayanan kesehatan di daerah bencana yang meliputi aspek kuratif, preventif, rehabilitatif, promotif, dan advokasi serta mengikuti peraturan dan perundang-undangan kesehatan di Republik Indonesia. Keempat yaitu Sekolah Cendekia BAZNAS (SCB) adalah sekolah bebas biaya dan berasrama bagi duafa untuk putra-putri Indonesia. Yang kelima yaitu Lembaga Beasiswa BAZNAS (LBB), merupakan program khusus Divisi Pendistribusian dan Pendayagunaan Zakat yang bertugas menjamin keberlangsungan program pendidikan bagi golongan kurang mampu/miskin sebagai pertanggungjawaban antargenerasi sekaligus menyiapkan generasi penerus bangsa yang memiliki kedalaman ilmu pengetahuan dan keluhuran akhlak.

Sedangkan produk dakwah dan advokasi, ada dua program, yaitu MCB dan Pusat Kajian Strategis BAZNAS. Mualaf Center BAZNAS (MCB) adalah program yang bertugas melakukan pembinaan dan pendampingan kepada mualaf sesuai tuntunan syariat Islam agar menjadi muslim dan muslimah kafah. Sedangkan PUSKAS BAZNAS, adalah program yang bertujuan 
mendukung realisasi pembangunan lembaga zakat profesional melalui program berbasis penelitian. Dengan demikian, pendirian Pusat Kajian Strategis, BAZNAS yang berfungsi sebagai pusat penyebaran pengetahuan dan keunggulan intelektual dapat menjadi elemen dasar untuk memenuhi visi BAZNAS.

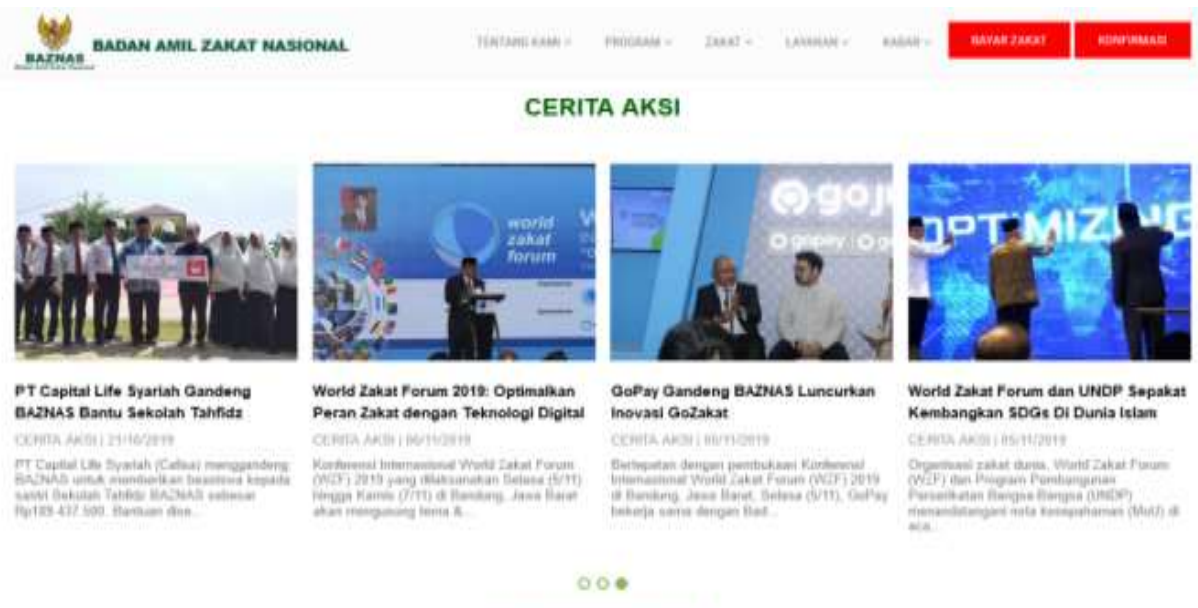

PROGRAM ZAKAT

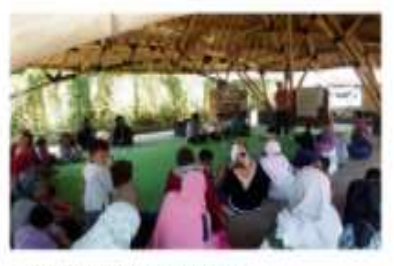

Zakat Community Denulogensent

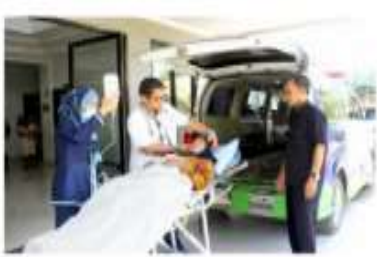

Rumah tathat Bazias

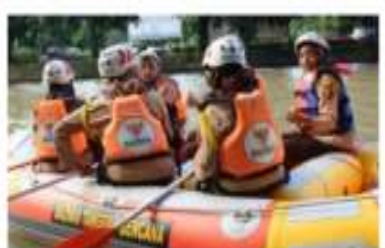

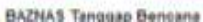

Gambar 2. Tampilan Cuplikan Artikel dari Pemanfaatan Dana ZIS yang Diwujudkan dalam Beberapa Program Kegiatan

Beberapa teks headline berita aksi memberikan informasi kepada komunikan bahwa BAZNAS memiliki program-program yang dalam pelaksanaannya tidak jarang juga berkolaborasi dengan organisasi maupun lembaga lain. Hal ini bisa menjadi daya tarik sebagai sebuah pesan rational appeal. Pesan ini memberikan pemahaman kepada komunikan bahwa penggalangan dana ZIS mampu memberikan banyak kontribusi kepada masyarakat dengan juga turut serta bekerja sama dengan sektor dan lembaga selainnya. Inilah yang menunjukkan bahwa kualitas program dari BAZNAS merupakan sebuah program yang luar biasa karena juga didukung oleh lembaga maupun organisasi yang mapan (hal ini membuktikan juga bahwa pesan promosi dalam baznas.go.id juga mengandalkan aspek message source. Pembahasan mengenai message source akan dibahas lebih mendalam pada variabel message source).

Di bawah cerita aksi dan program zakat, terdapat segmen headline news. Headline news ini berisi perkembangan informasi program-program BAZNAS, dengan format pesan berupa video YouTube. Video ini akan me-link ke YouTube dan dapat diputar (ditonton) langsung melalui website, atau diputar di situs youtube.com. 
HEADLINE NEWS
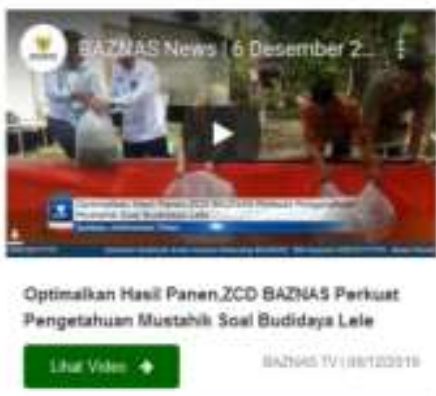

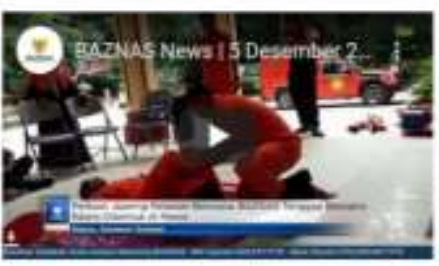

Pertuat Jejaring Reiman Bencans, Bazwus

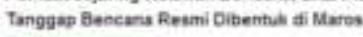

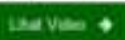

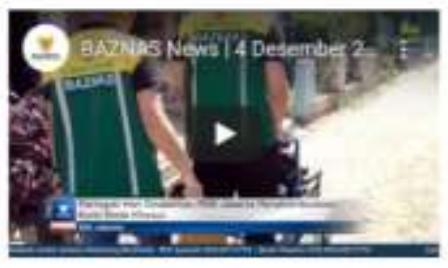

Peringati hari Disabilitas, RsE Jaiarta Mendistribusilan Kursi roda KChusus wavern $\rightarrow$

0000

Gambar 3. Tampilan Beberapa Headline News

Konten headline news juga selalu di posisi atas. Jika kita mengambil tiga sampel penulisan judul video di atas, maka dapat dilihat bentuk pesan promosi program BAZNAS. Pertama dalam judul “Optimalkan Hasil Panen, ZCD BAZNAS Perkuat Pengetahuan Mustahik Soal Budidaya Lele." Teks pesan ini memiliki arti tentang manfaat dari pengelolaan ZIS bisa membuat program budidaya yang bisa memajukan masyarakat. Hal ini adalah pendekatan rational appeal lewat pemberdayaan masyarakat. Judul kedua, yaitu "Perkuat Jejaring Relawan Bencana, BAZNAS Tanggap Bencana Resmi dibentuk di Maros." Teks pesan ini memiliki arti bahwa pengelolaan ZIS oleh BAZNAS bisa membantu dalam program bencana. Begitu pula judul ketiga, yaitu "Peringati Hari Disabilitas, RSB Jakarta mendistribusikan kursi roda khusus." Dari dua judul ini, bisa dianalisis bahwa pesan promosi yang disampaikan juga tetap menggunakan pendekatan rational appeal. Yaitu pemberian bantuan bencana dan pemberian roda khusus sebagai bentuk manfaat dari pengelolaan ZIS yang dibayarkan oleh para muzaki.
Konten rational appeal bisa dilihat juga bagaimana baznas.go.id memberikan deskripsi program-programnya. Sebagai contoh konten pesan yang ada dalam program microfinance. Berikut pesan penjelasan mengenai program microfinance:

BAZNAS adalah lembaga bantuan pembiayaan produktif kepada mustahik dengan prinsip not for profit dalam rangka pengembangan usaha. Permodalan merupakan faktor utama yang diperlukan untuk mengembangkan suatu unit usaha. Kurangnya permodalan pada usaha kecil menengah dikarenakan karakteristik usaha yang tertutup, mengandalkan modal dari si pemilik yang jumlahnya sangat terbatas, sedangkan modal pinjaman dari bank atau lembaga keuangan lainnya sulit diperoleh karena persyaratan secara administratif dan teknis yang diminta oleh bank tidak dapat dipenuhi.

Tujuan utama adalah memberikan akses layanan pembiayaan produktif kepada mustahik dalam rangka mengembangkan usahanya.

Kriteria usaha yang dapat dibiayai:

1. Sudah berjalan selama satu tahun terakhir dengan konsep usaha yang jelas.

2. Membuat Surat Keterangan Usaha minimal dari Kelurahan.

3. Memiliki catatan pembukuan kegiatan usaha yang dapat menilai aset.

4. Memiliki rekening bank. 
Status Pendanaan

Hibah bersyarat, para nasabah wajib mengangsur cicilan sebesar $10 \%$ dari nilai total pendanaan tiap bulan selama sepuluh bulan. Dana tersebut nantinya akan menjadi tambahan modal bagi para nasabah tanpa mengajukan kembali kepada Bank Mustahik.

Konten promosi program microfinance menjelaskan tentang latar belakang serta tujuan program. Selain itu juga menjelaskan prasyarat dalam mengikuti program. Konten-konten manfaat program ini ada di program-program selainnya, baik itu program ekonomi, sosial, maupun dakwah. Pesan promosi rational appeal disampaikan juga pada program-program ini. Selain manfaat program, juga terdapat konten pesan rational appeal dalam program seperti realisasi program selama ini termasuk jangkauan wilayahnya.

Pesan promosi dengan pendekatan emotional appeal juga bisa ditemui pada gambar utama yang ada pada program pemberdayaan ekonomi. Pendekatan yang digunakan adalah menggugah lewat rasa takwa kepada Allah Swt. sebagai bagian dari kebanggaan seorang muslim. Berikut contoh bentuk pesan promosi menggunakan emotional appeal pada baznas.go.id:

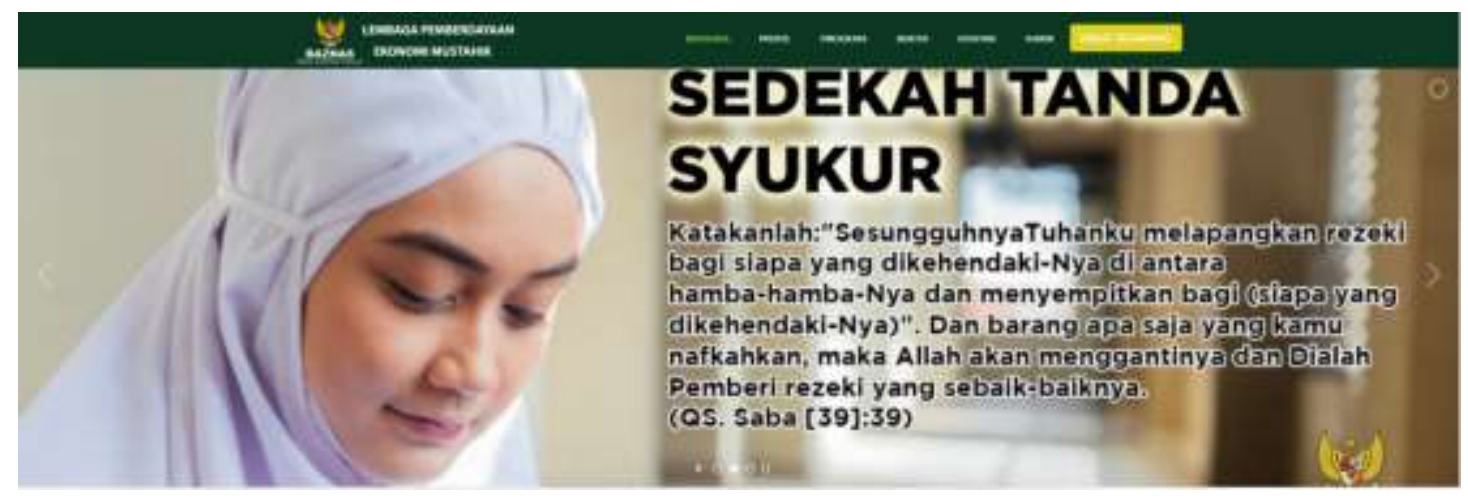

Gambar 4. Pesan promosi dengan pendekatan emotional appeal dengan simbol pesan perempuan yang beribadah serta teks pesan ayat Al-Qur'an

Konten di atas menggunakan gambar seorang perempuan muslim yang sedang menggunakan mukena. Mukena adalah salah satu simbol dari seorang perempuan muslim yang sedang menjalankan ibadah salat. Lalu diikuti dengan kutipan ayat suci Al-Qur'an yaitu surah Saba ayat ke-39, "Sesungguhnya Tuhanku melapangkan rezeki bagi siapa yang dikehendaki-Nya di antara hamba-hamba-Nya dan menyempitkan bagi (siapa yang dikehendaki-Nya). Dan barang apa saja yang kamu nafkahkan, maka Allah akan menggantinya dan Dialah Pemberi rezeki yang sebaik-baiknya." Dalam kutipan ayat terdapat dua emotional appeal. Yaitu emosi positif dengan bentuk rasa senang, yaitu Allah akan memberikan kelapangan rezeki bagi siapa saja yang dikehendaki. Di sisi lain juga ada muatan emosi negatif dengan bentuk rasa khawatir, yaitu Allah juga bisa saja menghendaki orang-orang tertentu untuk sempit rezekinya.

BAZNAS sebagai lembaga resmi pemerintah yang melakukan pengelolaan zakat, memberikan penjelasan kepada konsumen bahwa pengelolaan zakat yang dilakukan 
oleh BAZNAS bersifat akuntabel. Hal ini diwujudkan dalam bentuk pemberian bentuk laporan keuangan serta hasil audit dari lembaga independen. Infomasi mengenai audit ini bisa konsumen lihat dan dapatkan melalui konten publikasi laporan keuangan. Konten laporan keuangan berisi tentang laporan bulanan dan tahunan yang dibuat oleh internal BAZNAS, dan publikasi laporan dari auditor independen. Laporan ini dapat diakses sejak tahun 2002 hingga 2017. ${ }^{26}$ Konten pesan ini dapat dikategorisasikan sebagai rational appeal. Karena dengan laporan ini, BAZNAS hendak menunjukkan bahwa ketika menyalurkan zakat melalui BAZNAS, pengelolaan keuangannya dilakukan secara baik dan akuntabel. Sehingga komunikan dan calon konsumen, tidak perlu khawatir atas dana ZIS yang disalurkan melalui BAZNAS. Hal ini tentu bisa menjadi poin menarik bagi konsumen mengingat akuntabilitas suatu lembaga sangat diperlukan untuk konsumen agar tidak ada perasaan waswas akan penyalahgunaan dana yang telah terkumpul dari masyarakat.

Melalui baznas.go.id, BAZNAS juga menunjukkan keunggulan dari pengelolaan zakat yang telah dilakukan. Keunggulan tersebut yaitu berupa penghargaanpenghargaan yang diraih oleh BAZNAS. Penghargaan tersebut yaitu tahun 2008 BAZNAS mendapatkan sertifikat ISO 9001:2000, tahun 2009, 2010 dan 2011 BAZNAS kembali berhasil memperoleh sertifikat ISO untuk seri terbarunya (ISO 9001:2008) di mana BAZNAS adalah lembaga pertama yang memperoleh sertifikat ISO 9001:2008 untuk kategori seluruh unit kerja pada tahun 2009. Tahun 2009, BAZNAS mendapatkan penghargaan The Best Quality Management dari Karim Business Consulting. BAZNAS berhasil memperoleh predikat Laporan Keuangan Terbaik untuk Lembaga Non Departemen versi Departemen Keuangan RI tahun 2008. BAZNAS meraih "The Best Innovation Programme" dan "The Best in Transparency Management" pada IMZ Award 2011. BAZNAS menerima penghargaan Global Islamic Finance Awards 2018 di Bosnia Herzegovina. BAZNAS menerima penghargaan $4^{\text {th }}$ Global Good Governance 2019.

Konten pesan yang berisi penghargaan yang telah diraih, dapat memunculkan ketertarikan melalui emotional appeal, yaitu perasaan senang dan bangga akan lembaga yang teruji secara kinerja. Penulis tidak mengategorikan hal ini sebagai rational appeal karena pada dasarnya manfaat dari program tidak terjelaskan dalam konten ini, tetapi lebih kental dalam hal emosi atau rasa yang didapatkan ketika komunikan mengetahui bahwa lembaga yang selama ini menjadi rujukan penyaluran ZIS, ternyata memilki beragam penghargaan.

\section{Message Structure}

Pada pesan promosi website baznas.go.id, memang bukan satu pesan tunggal seperti bentuk naskah tunggal narasi. Namun terdiri dari bagian-bagian yang di dalamnya terdapat konten-konten tentang produk ZIS serta program hasil pengelolaan ZIS oleh BAZNAS. Pada konten-konten gambar utama, pesan yang disampaikan langsung pada tujuan inti pesan. Seperti promosi akan pentingnya zakat perusahaan bagi masyarakat yang kurang mampu. Namun

26 Saat penelitian dilakukan, hanya tahun 2006 dan 2018 yang tidak/belum bisa diakses 
untuk pesan-pesan berbentuk narasi paragraf, bisa ditemukan dalam konten promosi program, lewat artikel yang ada dalam segmen cerita aksi. Karena pola penulisan artikel hampir memiliki kesamaan, pada pembahasan kali ini, akan penulis sajikan cuplikan bentuk narasi teks artikel dalam konten cerita aksi:

\section{BAZNAS Gerakkan Warga Bersihkan Tempat Ibadah Pasca-banjir}

Seusai banjir melanda Jakarta, Bogor, Depok, Tangerang, dan Bekasi (Jabodetabek) tumpukan sampah dan endapan lumpur terlihat di berbagai tempat. BAZNAS menggerakkan warga untuk membersihkan berbagai fasilitas umum agar segera berfungsi kembali.

Ketua BAZNAS, Prof. Dr. Bambang Sudibyo, MBA, $C A$ turut membersihkan mushola di wilayah Pengadegan, Pancoran, Jakarta Selatan, Senin (6/1). Wilayah ini menjadi salah satu yang terparah sejak banjir melanda pada Rabu (1/1) dini hari.

Pada sebagian wilayah tersebut, hingga saat ini air masih menggenangi rumah-rumah. Sejumlah warga juga masih menghuni tempat pengungsian. Bambang Sudibyo mengatakan, bencana banjir ini membutuhkan penanganan bersama dari seluruh pihak, baik pemerintah maupun partisipasi masyarakat. Termasuk organisasi pengelola zakat.

BAZNAS yang menjadi koordinator lembaga zakat nasional, memiliki tanggung jawab membantu masyarakat yang tertimpa musibah. "Karena bencana yang datang tanpa memandang kemampuan ekonomi dan status sosial, selalu berpotensi menimbulkan masalah kemiskinan baru. Apalagi bagi warga yang sebelum bencanapun memiliki kemampuan ekonomi yang lemah, akan makin menderita dengan bencana ini," kata Bambang.

Banjir pada tahun baru 2020 ini memiliki sebaran yang luas dengan dampak kerugian dan korban jiwa yang tidak sedikit. Sehingga BAZNAS terus menggerakkan partisipasi masyarakat untuk turut serta membantu korban, baik dengan doa, tenaga, maupun materi. Melalui donasi masyarakat, BAZNAS terus membantu warga terdampak banjir melalui program penanganan baik pada masa tanggap darurat maupun masa pemulihan.

Saat ini tim berfokus pada bantuan dasar, air bersih, dan dukungan psikososial. BAZNAS juga membuka layanan tambahan seperti servis dan cuci motor gratis di posko pengungsian, agar kendaraan warga yang ikut terdampak dapat digunakan untuk mencari nafkah kembali. Sejak banjir melanda, BAZNAS telah membantu evakuasi sedikitnya di 10 titik Jabodetabek, melayani pengungsi di titik pengungsian dengan mendirikan 13 dapur umum dan dapur air.

Dari uraian artikel di atas, conclusion drawing ditutup dengan teks pesan bahwa melalui donasi masyarakat, BAZNAS telah membantu warga terdampak banjir. Selain itu juga ditekankan bahwa sedikitnya sudah ada 10 titik evakuasi yang dilakukan dan telah mendirikan 13 dapur umum dan dapur air. Dari sini bisa ditarik bahwa dalam artikel, BAZNAS memberikan penekanan kesimpulan kepada konsumen bahwa BAZNAS melaksanakan program dengan baik dalam membantu korban bencana.

Konten di atas juga merupakan sebuah struktur pesan dengan menggunakan onesided argument, yang artinya BAZNAS fokus untuk memberikan penjelasan mengenai manfaat-manfaat dalam program yang dilaksanakan. Kendala ataupun kekurangan program tanggap bencana, tidak terdapat dalam artikel. Hal ini bisa saja memang dalam pelaksanaan programnya, semua berjalan dengan baik. One-sided argument pada penjelasan program, dapat membuat komunikan makin tertarik untuk turut serta mendukung program dengan cara menunaikan ZIS melalui BAZNAS. Terlebih dalam conclusion artikel di atas, secara spesifik menyebutkan kalimat "melalui donasi masyarakat," di mana hal ini 
memberikan penekanan bahwa hasil program ini juga tidak lepas dari kontribusi masyarakat yang telah mempercayakan BAZNAS dalam mengelola dana ZIS. Urutan penyampaian dimulai dengan memberikan kondisi masyarakat sebelum dibantu program. Setelah itu dilanjutkan dengan pokok pikiran tentang program atau bantuan yang diberikan oleh BAZNAS serta manfaatnya bagi masyarakat yang dibantu. Sehingga secara urutan presentasi, konten pesan yang berisi manfaat besar dari program, berada di bagian akhir. Hal ini sesuai dengan apa yang disampaikan oleh
Fandy bahwa urutan klimaks ini memang cocok untuk bentuk pesan yang menggunakan one-sided arguments.

\section{Message Format}

Message format pada baznas.go.id menggabungkan beberapa macam bentuk pesan mulai dari tulisan, gambar, serta video. Format pesan promosi pada tampilan homepage BAZNAS didominasi oleh gambar serta cuplikan beberapa artikel. Untuk lebih jelasnya berikut penulis gambarkan bentuk format pesan dalam homepage-nya:

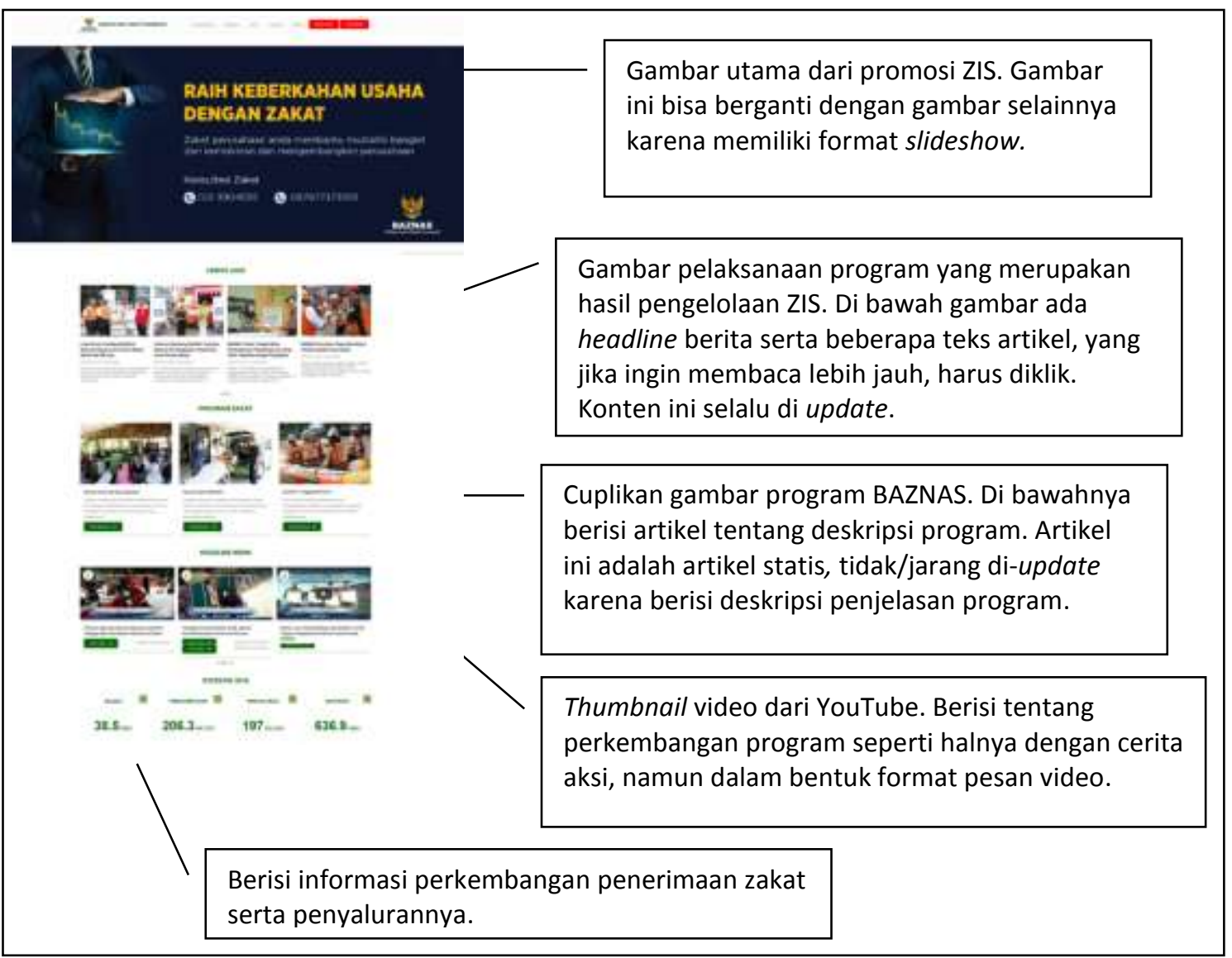

Gambar 5. Message Format pada Homepage baznas.go.id

Kombinasi format pesan dari bentuk teks, gambar, slideshow, serta video tentu bisa menjadi daya tarik tersendiri bagi komunikan. Hal ini karena tampilan yang dilihat bukan sebuah tampilan monoton. Selain itu, isi kontennya juga memberikan 
informasi mengenai produk dan program dari BAZNAS. Format pesan artikel aksi, memiliki dua bentuk format pesan, yaitu gambar dan uraian. Di mana gambar merupakan cuplikan kegiatan (dokumentasi) lalu diikuti dengan uraian dari kegiatan. Kualitas gambar dari cuplikan kegiatan boleh dibilang bagus karena tampak jelas (tidak blur) saat dilihat. Warna yang ditampilkan juga tampak cerah dan tidak redup. Penggunaan kualitas gambar yang bagus ini membuat komunikan bisa melihat dengan baik bagaimana gambaran program yang telah dilaksanakan oleh BAZNAS. Kualitas gambar yang bagus juga akan memberikan kesan positif bahwa pelaksanaan program dilaksanakan dengan baik, termasuk dalam hal pendokumentasian kegiatan.

Pada bagian artikel deskripsi program, terdapat format pesan yang berbentuk infografik. Format pesan dengan menggunakan infografik dapat menjadi daya tarik bagi komunikan untuk membaca informasi secara ringkas namun dengan tampilan yang menarik. Format pesan ini dapat memberikan gambaran kepada komunikan tentang wilayah-wilayah yang telah terbantukan lewat program ZCD.
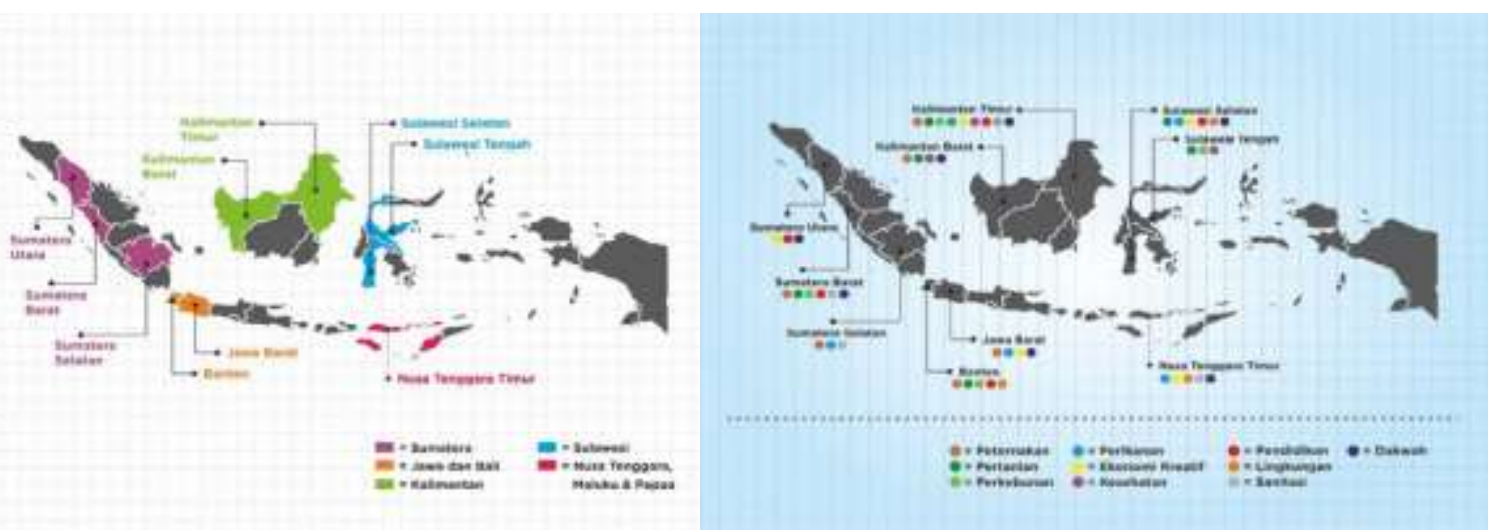

Gambar 6. Salah Satu Format Pesan Berbentuk Infografik Sebaran Program Zakat Community Development (ZCD) BAZNAS

Warna yang dipilih dari infografik di atas juga sangat bagus dengan pemilihan warna yang kontras antara satu warna dengan warna selainnya. Penggunaan warna yang kontras akan mempermudah komunikan dalam memahami isi konten yang ada dalam infografik. Indeks dari penggunaan simbol warna, juga dijelaskan di bawah infografik untuk memberikan keterangan mengenai makna dari simbol-simbol tersebut. Kombinasi peta Indonesia dengan simbol ini tentu sesuai dengan tujuan pesan ingin menunjukkan sebaran program dari program ZCD yang ada di Indonesia. Lewat infografik ini, komunikan bisa mengetahui sejauh mana keluasan jangkauan dari program ZCD yang telah dilakukan oleh BAZNAS.

Warna dominan yang digunakan dalam seluruh isi konten yang ada di baznas.go.id, adalah menggunakan warna hijau. Mulai dari homepage, hingga tampilan dari bentuk salah satu fitur live chat, juga menggunakan 
busana hijau. Menurut penulis, salah satu penggunaan format message dengan menggunakan warna hijau ini, merupakan warna brand BAZNAS. Sehingga sering diulang-ulang, dan direpetisi. Pengulangan warna ini menjadi promosi secara halus karena akan tertanam kepada benak komunikan tentang warna hijau yang terasosiasi dengan BAZNAS.

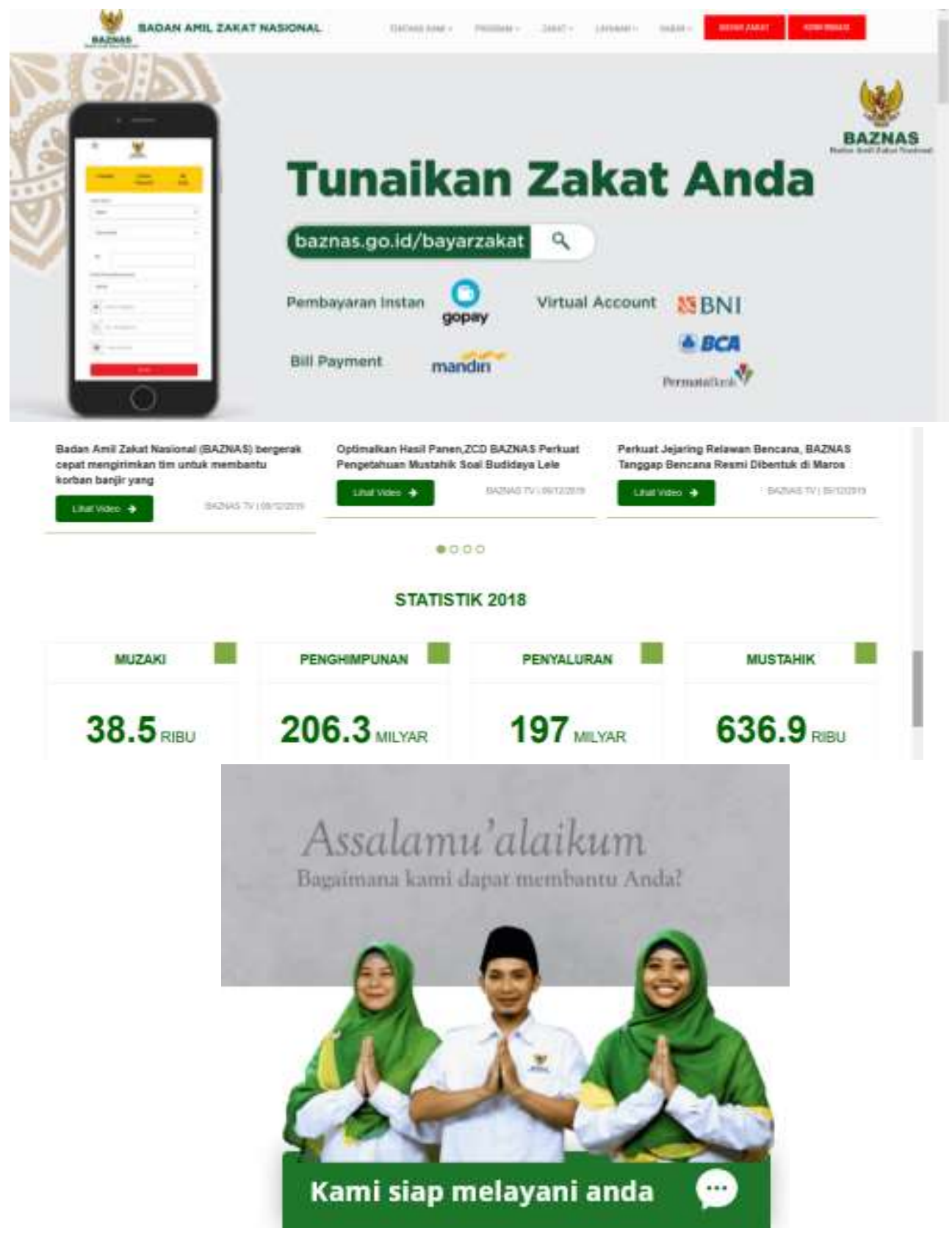

Gambar 7. Format Pesan dengan Menggunakan Warna Dominan Hijau Sebagai Salah Satu Warna Brand dari BAZNAS 
Format pesan video yang terdapat pada headline news ditampilkan dengan menggunakan media pemutar utama YouTube. Kualitas video yang ditampilkan dalam format video ini bisa dilihat hingga kualitas full high definition (FHD) atau dalam rasio $1080 \times 1920$ pixel. Dengan kualitas FHD ini, kegiatan program dapat terlihat dengan jelas dan baik, karena tidak ada gambar yang buram. Durasi video dari headline news pada saat penelitian ini, hanya satu video yang berdurasi lebih dari 5 menit (satu video berdurasi 6 menit). Durasi yang kurang dari 5 menit ini merupakan format pesan dengan model konten pesan berbentuk highlight. Maksud dari highlight adalah isi konten berita menginformasikan pesan-pesan yang penting dan utama dalam kegiatan tersebut. Sehingga komunikan tidak jenuh dengan pemberitaan dan bisa langsung mengerti poin-poin penting dalam kegiatan yang dilakukan oleh BAZNAS. Format penyampaian promosi program lewat headline News ini menyerupai sebuah berita televisi dengan seorang penyiar berita dan kemudian dilanjutkan dengan video kegiatan beserta suara narator sebagai pengiring informasi berita. Pesan yang berformat video berita dapat memberikan kesan bahwa apa yang disampaikan oleh BAZNAS adalah kegiatan yang real, akurat, dan tepercaya. Seperti halnya dalam sebuah konten berita di media televisi yang menekankan fakta serta keakuratan berita yang disampaikan.

Dalam mempromosikan zakat, infak, dan sedekah, baznas.go.id juga menyediakan format pesan yang berbentuk QR Code sebagai salah satu cara pembayaran ZIS lewat e-commerce maupun dompet digital. Format pesan ini berupa gambar QR Code yang jika di-scan, dapat terhubung dengan akun e-commerce maupun dengan akun dompet digital. Format pesan ini dapat memudahkan komunikan untuk mempersingkat waktu menuju pembayaran. Jika format teks biasanya berbentuk link, maka dengan QR Code ini komunikan hanya tinggal scan dengan smartphone yang dimiliki, kemudian otomatis dihubungkan secara langsung dengan akun yang bersangkutan.

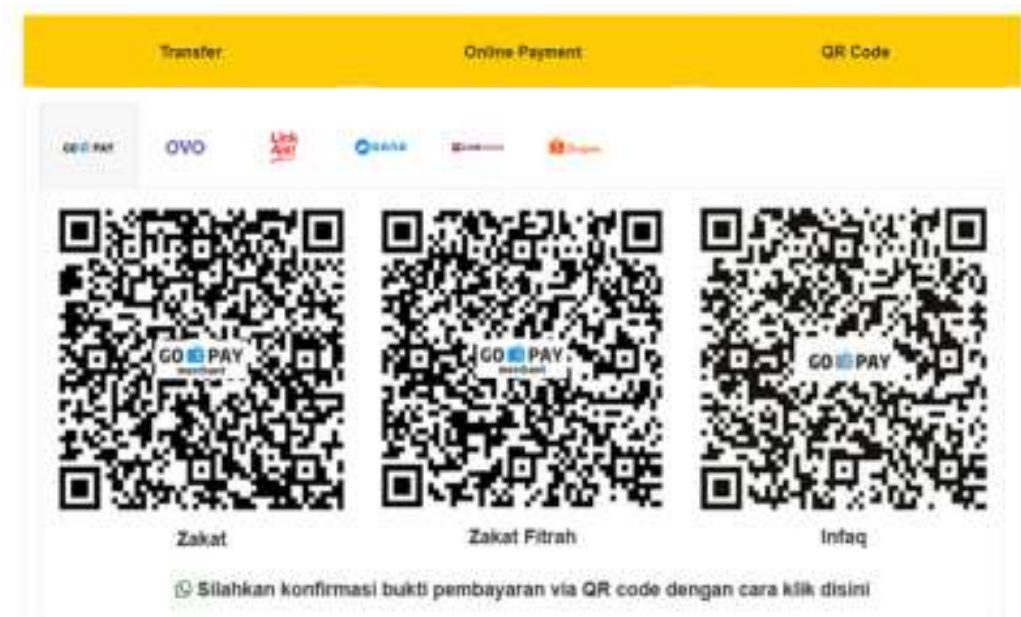

Gambar 8. Format Pesan Berbentuk QR Code dalam Pembayaran ZIS 
Format font (bentuk huruf) yang banyak digunakan dalam penulisan artikel kegiatan sebagai salah satu bentuk promosi, menggunakan huruf berjenis calibri dan times new roman. Penggunaan huruf ini sangat sesuai karena tidak menyulitkan komunikan dalam membaca. Karena tujuan artikelnya adalah fokus pada kontennya, maka tidak perlu menggunakan huruf yang terlalu banyak lekukan atau terlalu artistik. Penggunaan huruf yang artistik biasanya digunakan untuk memuat sebuah pesan yang mengutamakan keindahan. Pada website ini, hal tersebut tidak ditonjolkan dan lebih menekankan bagaimana tulisantulisan dalam artikel yang ada di baznas.go.id bisa dibaca dan mudah dipahami oleh komunikan. Sehingga promosi program kegiatan pun lebih mengena. Format penulisan paragraf juga tidak begitu rumit. Setiap pokok pikiran selalu dipisah dengan paragraf baru untuk memberikan penekanan di setiap paragraf. Paragraf yang berisi penjelasan kondisi mustahik, akan berbeda paragraf dengan yang berisi pokok pikiran tentang jumlah bantuan program yang diberikan BAZNAS kepada mustahik.

Message format menyangkut headline, copy, ilustrasi, dan warna jika di media cetak. Pada media radio bisa seperti kata-kata, kualitas suara, dan vokalisasi. Pada iklan televisi bisa berkaitan dengan kata-kata, warna, ilustrasi, kualitas suara, headlines, copy, dan body language. Pada produk kemasan bisa berbentuk warna, tekstur, ukuran, bentuk, dan aroma. ${ }^{27}$

\section{Message Source}

Pesan-pesan yang disampaiakan oleh BAZNAS dalam mempromosikan produk maupun programnya, ditunjang dengan berbagai macam sumber. Sumber-sumber tersebut memiliki berbagai kredibilitas pesan. Di antaranya adalah sumber pesan yang berasal dari Al-Qur'an, hadis serta pendapat para ulama. Berikut sumber pesan yang digunakan untuk mempromosikan produk ZIS.

Tabel 1 - Message Source dalam Mempromosikan Produk ZIS

\begin{tabular}{cll}
\hline Jenis Message Source & & \multicolumn{1}{c}{ Message Source } \\
\hline \hline Nash Al-Qur'an & - Q.S. At-Taubah (9): 103 \\
& - Q.S. At-Taubah (9): 60 \\
& - Q.S. Saba (39): 39 \\
& - Q.S. Al-Baqarah (2): 267 \\
& - Q.S. Al-Baqarah (2): 271 \\
Hadis Nabi & H.R. Bukhari Muslim tentang zakat \\
Ulama & - Shaikh Yusuf Al-Qaradawi \\
& - Kesepatakan ulama pada Muktamar Internasional \\
& Pertama tentang zakat di Kuwait (29 Rajab 1404 H) \\
Lain - lain & Peraturan Menteri Agama
\end{tabular}

\footnotetext{
27 Fandy Tjiptono, 512.
} 
Al-Qur'an sebagai message source dari pesan promosi produk zakat, memiliki kredibilitas yang sangat kuat. Hal ini dikarenakan perintah zakat memang berasal dari perintah agama yang bersumber dari firman Allah. Meskipun mungkin sebagian konsumen sudah mengerti akan perintah untuk berzakat, namun dengan memberikan penekanan kembali bahwa perintah zakat adalah perintah langsung dari Allah, maka di sini termasuk dalam fungsi promosi untuk reminding tentang pentingnya melaksanakan kewajiban berzakat.

Begitu pula dengan message source yang berasal dari hadis Nabi. Hadis Nabi yang diambil sebagai pendasaran pun adalah salah satu hadis dari periwayat yang cukup terkenal serta cukup diakui kesahihannya, yaitu Bukhari dan Muslim. Secara expertise tentu sudah tidak perlu diragukan karena banyak pula ulama-ulama yang merujuk pada hadis yang diriwayatkan oleh Bukhari dan Muslim. Apalagi Bukhari menggunakan kriteria yang sangat ketat dalam menyeleksi hadis. Trustworthiness juga menjadi poin bagi Bukhari Muslim karena beliau berdua adalah ulama yang tepercaya dan dikenal dengan pribadi yang jujur. Secara likability, tentu beliau adalah ulama yang populer karana kitab hadisnya banyak digunakan sebagai rujukan ulama-ulama dalam mempelajari perintah dan larangan agama. ${ }^{28}$

Message source dalam pesan promosi program zakat selanjutnya adalah ulama Yusuf al-Qaradawi. Yusuf al-Qaradawi adalah cendekiawan muslim yang berasal dari Mesir. Beliau juga dikenal sebagai seorang

28 Muhammad Iqbal Syauqi. "Keutamaan 'Shahih alBukhari' dan 'Shahih Muslim'," NU.or.id, diakses 4 Januari 2020.

https://islam.nu.or.id/post/read/86584/keutamaanshahih-al-bukhari-dan-shahih-muslim mujtahid di era modern. Secara expertise, beliau adalah seorang doktor dalam bidang zakat, dan telah membuat sebuah buku fikih zakat yang membahas persoalan zakat dengan nuansa modern dengan sangat komprehensif. Sehingga secara pengetahuan tentang zakat sudah tidak perlu diragukan kembali. Secara trustworthiness, beliau juga dikenal dengan pribadi yang baik dan dapat dipercaya. Dan secara likability, beliau juga orang yang cukup populer serta fikih-fikihnya banyak dijadikan rujukan oleh para ulama selainnya. ${ }^{29}$ Message source selanjutnya adalah kesepakatan ulama pada Muktamar Internasional tentang zakat di Kuwait. Penulis belum bisa menemukan informasi detil tentang siapa saja ulama-ulama yang tergabung dalam muktamar tersebut. Namun penulis memiliki hipotesis bahwa peserta muktamar tentu orang-orang yang terpilih dan memiliki kapasitas dalam membahas tentang persoalan zakat.

Peraturan Menteri Agama sebagai salah satu message source, memiliki kredibilitas yang baik pula. Expertise tentu tidak diragukan karena kementerian agama adalah lembaga pemerintahan yang mengurusi masalah keagamaan. Trustworthiness sebagai lembaga pemerintah yang legal, menjadikan kepercayaan pesan promosi menjadi lebih kuat karena bukan berasal dari lembaga abal-abal yang bisa jadi ada kepentingan tertentu. Likability, meskipun peraturan menteri bukan berpatok pada perorangan, namun peraturan menteri merupakan salah satu sumber hukum legal yang diakui oleh seluruh masyarakat Indonesia. Sehingga

29 Roni Wijaya, "Biografi Dr. Yusuf Al-Qaradhawi," bio.or.id, diakses 4 Januari 2020. https://bio.or.id/biografi-dr-yusuf-al-qaradhawi/ 
penggunaan dasar menggunakan peraturan menteri, sudah dikenal oleh masyarakat muslim di Indonesia.

Untuk mempromosikan program hasil pengelolaan zakat, dalam artikel aksi perkembangan programnya, penulis belum menemukan adanya endorsement seperti menggunakan artis ataupun selebritas. Namun pada beberapa program aksinya, tertulis di artikel bahwa ada beberapa figur publik yang juga ikut serta dalam programnya. Berikut beberapa sampel berita aksi dan message source dari figur publik:

Tabel 2 - Cuplikan Message Source Beserta Pesan yang Disampaikan dalam Artikel Aksi pada baznas.go.id

\begin{tabular}{ll}
\hline Message Source & \multicolumn{1}{c}{ Bentuk Teks Tulisan } \\
\hline \hline Direktur & Evi Lionawan mengatakan, Lotte Grosir menyampaikan keprihatinannya \\
Marketing Lotte & terhadap para korban banjir, terutama yang masih harus mengungsi karena \\
Grosir, Evi & kondisi rumah yang rusak akibat banjir. \\
Lionawan & "Lotte Grosir sangat concern terhadap para korban banjir Jabodetabek, mudah- \\
& mudahan tahun depan dapat ditanggulangi lebih baik. Untuk membantu korban \\
& ini, kami bekerja sama dengan BAZNAS. Kami sudah lama kerja sama dengan \\
& BAZNAS dengan banyak program usaha bagi yang membutuhkan. Nah kenapa \\
& tidak pada saat banjir ini kita minta tolong ke BAZNAS untuk menyalurkan \\
bantuan kepada korban," katanya. & \\
Head of & Nurdiana Darus mengatakan pihaknya memberikan bantuan barang sejumlah \\
Corporate Affairs & 93.000 unit. Sebanyak 43.000 unit di antaranya didistribusikan pada sepuluh titik \\
Unilever & posko pengungsian BAZNAS. \\
"Indonesia & kami yang bisa kami salurkan semoga bisa membantu para warga. Khusus hari ini \\
"Dendation & anak di sini secara psikologi agar mereka bisa kembali ceria setelah terdampak \\
& dari bencana banjir ini. \\
& "BAZNAS adalah mitra yang sangat dekat di hati kami, kami sudah bekerja sama \\
& dengan BAZNAS lumayan lama, tentunya BAZNAS adalah mitra yang bisa kami \\
percaya," ujarnya.
\end{tabular}

Artikel di atas meskipun ditulis oleh BAZNAS melalui website baznas.go.id, namun pada pesannya mencantumkan sumber kutipan, yaitu Direktur Marketing Lotte Grosir dan ketua Corporate Affairs Unilever Indonesia Foundation. Tokoh-tokoh ini memang bukan artis ataupun selebritas. Namun profil dari pada komunikan ini bisa menjadi pengangkat kredibilitas pesan yang disampaikan. Seperti Head of Corporate Affairs Unilever Indonesia Foundation, yang menyatakan penilaian beliau bahwa BAZNAS adalah mitra yang bisa dipercaya. Secara trustworthiness bisa ditunjukkan bahwa Unilever adalah pihak yang menjadi mitra dalam bantuan (bukan penerima bantuan). Meskipun secara personal, likability tidak seperti seorang artis. Begitu pula message source Direktur Marketing Lotte Grosir, Evi Lionawan. Beliau adalah direktur marketing dari salah satu pusat perbelanjaan yang ada di Indonesia. Tentunya, beliau juga akan selektif dalam memilih mitra penyaluran bantuan. Pada pesannya beliau menekankan bahwa BAZNAS adalah mitra kerja sama Lotte sejak lama. Secara expertise jika 
ditinjau dari jabatan beliau, tentu beliau bukan orang yang sembarangan dalam menjalin mitra untuk menyalurkan bantuan. Ditinjau dari trustworthiness, beliau juga bukan karyawan ataupun anggota dari BAZNAS. Namun secara kredibilitas likability, tidak banyak yang mengenal beliau.

Pada penjelasan mengenai message content, dijelaskan bahwa BAZNAS memiliki beberapa penghargaan yang diberikan oleh lembaga lain. Dari beberapa penghargaan tersebut, dapat dianalisis pula, message source dari lembaga atau orang yang memberikan penghargaaan. Pertama penghargaan tentang sertifikat ISO. Untuk diketahui bahwa International Organization for Standardization, atau lebih dikenal sebagai ISO, adalah salah satu standar internasional dalam sebuah sistem manajemen untuk pengukuran mutu organisasi. Mereka memegang peranan penting dalam mengukur bagaimana kredibilitas perusahaan yang ingin bersaing secara global dan juga adalah salah satu cara untuk meningkatkan sistem manajemen mutunya. Untuk mendapatkan standardisasi ISO sebuah perusahaan harus melalui sebuah siklus pasti yang dikenal dengan PDCA yakni identifikasi, analisis, dan eksekusi sebuah penyelesaian masalah untuk menjamin mutu internasional. Siklus atau prinsip ini adalah prinsip internasional yang juga diterapkan di segala jenis industri. Dari sini bisa diketahui bahwa tidak sembarang lembaga bisa mendapatkan sertifikat ISO. Maka dengan adanya kepemilikan sertifikat ISO oleh BAZNAS, menunjukkan bahwa BAZNAS adalah lembaga yang memang teruji dan kredibel. Maka dari itu sertifikat ISO ini memiliki kredibilitas secara expertise, karena dinilai oleh orang-orang yang memiliki keahlian dalam bidang penilaian standar kualitas suatu lembaga, kredibilitas trustworthiness karena penilaian dilakukan oleh lembaga di luar dari BAZNAS, dan likability karena standar ISO sudah cukup sering digunakan oleh lembaga-lembaga untuk mengukur kualitas lembaga atau perusahaannya.

BAZNAS mendapatkan penghargaan The Best Quality Management dari Karim Business Consulting. Karim Business Consulting adalah perusahaan konsultan dinamis yang mengkhususkan diri dalam Ekonomi dan Keuangan Islam yang didukung oleh orang-orang profesional yang bekerja penuh waktu. KARIM Consulting Indonesia didirikan pada Agustus 2001 dan memosisikan dirinya sebagai perusahaan konsultan syariat terkemuka di dunia (Dynamic consulting firm specializing in Islamic Economics and Finance supported by professional people working full time. KARIM Consulting Indonesia was established in August 2001 and positioned itself as a world leading Shariah Compliance consulting firm). Expertise dari pesan penghargaan ini tidak perlu diragukan karena diberikan oleh lembaga yang memang diisi oleh orangorang yang profesional di bidang ekonomi Islam dan keuangan syariat. Pesan penghargaan ini juga memiliki kredibilitas trustworthiness karena penilaian dilakukan oleh lembaga di luar BAZNAS. Karena perusahan bergerak di bidang consulting, maka secara kredibilitas likability hanya berpengaruh pada konsumen yang juga sering berkaitan dengan perusahaan consulting.

BAZNAS berhasil memperoleh predikat Laporan Keuangan Terbaik untuk Lembaga Non Departemen versi Departemen Keuangan RI pada tahun 2008. Secara 
expertise, Departemen Keuangan tentu diisi oleh mereka yang memang memiliki keahlian di bidang keuangan. Sehingga predikat laporan keuangan terbaik yang diberikan oleh Departemen Keuangan RI, tentu sangat kredibel. Pesan penghargaan ini juga memiliki kredibilitas trustworthiness karena penilaian dilakukan oleh lembaga di luar BAZNAS. Dan secara likability, masyarakat Indonesia sudah cukup populer dengan Departemen Keuangan RI. Sehingga hal ini tentu akan menambah kredibilitas pesan penghargaan yang disampaikan oleh BAZNAS.

BAZNAS meraih "The Best Innovation Programme" dan "The Best in Transparency Management" pada IMZ Award 2011. IMZ adalah lembaga konsultasi pemberdayaan dan manajemen organisasi nirlaba yang bergerak dalam bidang pelatihan, konsultasi, dan pendampingan, serta riset dan advokasi zakat/kemiskinan. Pesan penghargaan ini memiliki kredibilitas expertise karena diberikan oleh organisasi yang memang bergerak di bidang zakat. Pesan penghargaan ini juga memiliki kredibilitas trustworthiness karena penilaian dilakukan oleh lembaga nirlaba yang bukan bagian dari lembaga BAZNAS. Secara likability, IMZ memang tidak seterkenal Depertemen Keuangan RI. Namun bagi orang-orang yang bekerja di bidang manajemen zakat, bisa jadi sudah mengenal tentang lembaga IMZ. Sehingga likability dari pesan penghargaan ini memanglah terbatas.

BAZNAS menerima penghargaan Global Islamic Finance Awards 2018 di Bosnia Herzegovina. Global Islamic Finance Award (GIFA) adalah salah satu penghargaan yang sangat diidamkan dan paling terhormat dalam perbankan dan keuangan Islam di dunia. Ini adalah label keunggulan bergengsi yang mengakui pemerintah, lembaga, dan individu yang telah menunjukkan prestasi luar biasa di bidangnya masing-masing, berkontribusi pada keberlanjutan perbankan dan keuangan Islam sebagai sistem yang layak dalam arsitektur keuangan internasional global. Didirikan pada tahun 2011 oleh Edbiz Corporation sebagai bagian dari advokasi untuk perbankan dan keuangan Islam, GIFA merayakan pencapaian individu, lembaga, dan pemerintah dalam mempromosikan dan mengadvokasi perbankan dan keuangan Islam, dan memastikannya untuk tetap berkomitmen untuk tanggung jawab sosial. Sumber pesan penghargaan ini tentu sudah tidak diragukan lagi kredibilitas expertise dan trustworthiness-nya. Penghargaan ini diberikan oleh orang-orang yang memang kredibel dalam bidang keuangan Islam. Bahkan pada tingkat level dunia. Sehingga secara keahlian sudah tidak diragukan serta tingkat kepercayaannya juga tinggi karena dinilai oleh orang-orang yang berada di luar lingkungan BAZNAS. Meskipun memang kredibilitas likuidity tidak sampai pada masyarakat umum yang tidak memiliki pengetahuan tentang ekonomi Islam dunia.

Terakhir, BAZNAS menerima penghargaan $4^{\text {th }}$ Global Good Governance 2019. Global Good Governance Award (3G Awards) adalah program penghargaan yang menyoroti keunggulan dalam pemerintahan yang baik dan komitmen untuk kesejahteraan sosial dalam tiga aliran utama yaitu pemerintah dan politik, sektor korporat, dan sektor sosial dan filantropi. Penghargaan 3G mempromosikan tat kelola yang baik dan komitmen terhadp kesejahteraan. Penghargaan ini dikembangkan oleh Cambridge IFA (lembaga 
layanan keuangan yang mengkhususkan diri dalam mengembangkan dan memanfaatkan alat analitik canggih untuk mengevaluasi data bisnis, menilai indikator ekonomi makro dan tren pasar, positioning kepemimpinan dan pengembangan merek yang relevan dengan pengembangan industri jasa keuangan secara global). Sumber pesan penghargaan ini tentu sudah tidak diragukan lagi kredibilitas expertise dan trustworthiness-nya. Penghargaan ini diberikan oleh orang-orang yang memang kredibel dalam bidang keuangan hingga pada taraf global. Secara likability, memang tidak banyak dikenal oleh sebagian besar masyarakat Indonesia karena berada pada cakupan dunia dengan sektor spesifik pada organisasi nirlaba maupun bidang keuangan.

\section{Kesimpulan}

Message content pesan promosi yang disampaikan melalui baznas.go.id menggunakan pendekatan rational appeal dengan memberikan gambaran akan manfaat ketika komunikan menjalankan zakat. Terutama melalui BAZNAS yang mampu memberikan manfaat kepada masyarakat serta pengelolaan zakatnya yang akuntabel. Message content emosional appeal yang digunakan adalah menggunakan pendekatan emosi positif dengan menunjukkan konten-konten akan rasa senang dan bangga sebagai seorang muslim dalam melaksanakan ZIS sebagai bagian dari perintah agama. Rasa senang ini juga dimunculkan dengan pembuktian bahwa dana ZIS yang telah diberikan dikelola dengan baik oleh BAZNAS. Content moral appeal ditunjukkan dengan teks pesan maupun gambar bahwa pelaksanaan ZIS yang disalurkan kepada BAZNAS telah mampu membantu masyarakat lewat program pemberdayaan.

Message structure dalam pesan promosi melalui baznas.go.id, menggunakan conclusion drawing yang telah dikunci oleh BAZNAS agar komunikan tidak salah dalam mengambil kesimpulan dari artikel-artikel yang dibaca. Conclusion drawing ini diikuti dengan one-side argument di mana dalam pesan promosinya, BAZNAS fokus menjelaskan manfaat dan kelebihan. Alur presentasi yang digunakan yaitu dengan model klimaks di mana penjelasan manfaat program berada di bagian-bagian akhir artikel.

Message format pesan promosi baznas.go.id menggunakan variasi dari penggunaan tulisan, gambar, infografis, warna, dan video, dengan warna hijau sebagai bentuk format pesan warna yang utama yang ada di kontenkonten baznas.go.id. Kualitas gambar dan video jelas dan mampu memberikan gambaran kegiatan sebagai bagian dari dokumentasi. Pada resolusi videonya berada pada resolusi full high definition.

Message source pada baznas.go.id tidak menggunakan artis ataupun selebritas. Namun di beberapa artikel menggunakan message source yang secara kredibilitas pesan sangat baik. Terutama pada pesan penghargaan yang diraih, message source memiliki expertise dan trustworthiness hingga pada tingkat dunia. Meskipun secara likability, mungkin tidak seterkenal artis maupun selebritas. Hal ini karena message source berasal dari kelembagaan dan kelembagaan tersebut berada pada bidang keahlian yang spesifik. 


\section{Bibliografi}

Akhmadi, Ditya Pandu. "Cara Bayar Zakat Online Melalui Situs Web Baznas." Tirto.id. Mei 8, 2019. https://www.tirto.id/cara-bayar-zakat-online-melalui-situs-web-baznas-dtLd

Arikunto, Suharsimi. Prosedur Penelitian Suatu Pendekatan Praktik. Edisi Revisi 6. Jakarta: Rineka Cipta, 2009.

Baznas. https://baznas.go.id/

Bekti, Humairah Bintu. Mahir Membuat Website dengan AdobeDreamweaver CS6, CSS, dan JQuery. Yogyakarta: Andi, 2015.

Fiqhyany, Milla Rahma dan Ari Prasetyo. "Pengaruh Komunikasi Pemasaran Terpadu Terhadap Niat Muzakki Membayar Dana Zakat, Infaq, Shadaqah Pada Yayasan Nurul Hayat Cabang Tuban." Jurnal Ekonomi Syariah Teori dan Terapan, Vol. 1 No. 11 (2014). http://dx.doi.org/10.20473/vol1iss201411pp\%25p

Kasumaningrum, Yulistyne. "Dana Zakat yang Dihimpun Lewat Teknologi Digital Setiap Tahun Meningkat." PikiranRakyat.com. Oktober 3, 2019. https://www.pikiranrakyat.com/ekonomi/pr-01320418/dana-zakat-yang-dihimpun-lewat-teknologi-digitalsetiap-tahun-meningkat

Kotler, Philip dan Kevin Lane Keller. Manajemen Pemasaran. Jakarta: Erlangga. 2010.

Lestarsi, Sinta Petri. "Hubungan Komunikasi Pemasaran dan Promosi dengan Keputusan Kemilih Jasa Layanan Kesehatan (Studi pada Rumah Sakit Islam Lumajang)." Interaksi: Jurnal IImu Komunikasi, Vol. 4 No. 2 (2015): 139-147. https://doi.org/10,14710/interaksi.4.2.139147.

Lupiyoadi, Rambat. Manajemen Pemasaran Jasa Berbasis Kompetensi. Edisi 3 Jakarta: Salemba Empat, 2013.

Naibaho, Walvin dan Firdaus Yusrizal. "Efektivitas Website Dinas Pariwisata Dan Kebudayaan Provinsi Jawa Barat Sebagai Media Informasi Bagi Wisatawan." JOM FISIP, Vol. 4 No. 2 (2017): 1-12. https://jom.unri.ac.id/index.php/JOMFSIP/article/view/16190

Pradiani, Theresia. "Pengaruh Sistem Pemasaran Digital Marketing terhadap Peningkatan Volume Penjualan Hasil Industri Rumahan." Jurnal JIBEKA, Vol. 11 No. 2 (2017): 46-53. https://doi.org/10.32812/jibeka.v11i2.45

Pujiriyanto. Desain Grafis Komputer: Teori Grafis Komputer. Yogyakarta: Andi, 2005.

Ranawati, Nur Khansa. "BAZNAS Targetkan 15\% Penerimaan Zakat dari Layanan Digital." $\begin{array}{lll}\text { AyoBandung.com. November } & 6019 .\end{array}$ https://www.ayobandung.com/read/2019/11/06/69347/baznas-targetkan-15penerimaan-zakat-dari-layanan-digital

Riyanto, Andi Dwi. "Pembuatan Website Sebagai Media Promosi yang Terpecaya." Seminar Nasional Informatika (SEMNASIF), Vol. 1 No.1 (2015): 103.23.20.161/index.php/samnasif/article/view/1362.

Rohim, Ade Nur. "Optimalisasi Penghimpunan Zakat Melalui Digital Fundraising." Al-Balagh: Jurnal Dakwah dan Komunikasi, Vol. 4, No. 1 (2019): 59-90. Doi: 10.22515/balagh.v4i1.1556 
Syauqi, Muhammad Iqbal. "Keutamaan 'Shahih al-Bukhari' dan 'Shahih Muslim'." NU.or.id. Januari 4, 2020. https://islam.nu.or.id/post/read/86584/keutamaan-shahih-al-bukharidan-shahih-muslim

Tarsani. "Strategi Komunikasi Pemasaran Dompet Dhuafa Dalam Meningkatkan Kepercayaan Muzakki." Bricolage: Jurnal Magister Ilmu Komunikasi, Vol. 2 No. 1 (2017). 56-70. http://dx.doi.org/10.30813/bricolage.v2i01.834

Tjiptono, Fandy. Strategi Pemasaran. Edisi III. Yogyakarta: Andi, 2008.

Wijaya, Roni. "Biografi Dr. Yusuf Al-Qaradhawi." bio.or.id. Januari 4, 2020. https://bio.or.id/biografi-dr-yusuf-al-qaradhawi/

“Baznas Targetkan Himpun Zakat Rp 3,5 Triliun di Ramadan.” Liputan6.com. September 5, 2019. https://www.liputan6.com/ramadan/read/3970782/baznas-targetkan-himpun-zakat-rp35-triliun-di-ramadan

"Pengumpulan Zakat 2019 Lampaui Target." Media Indonesia. Desember 30, 2019. https://mediaindonesia.com/read/detail/280014-pengumpulan-zakat-2019-lampauitarget 
Bagus Wira Prasetia

260 | INTELEKSIA - Jurnal Pengembangan IImu Dakwah 